\title{
THEORETICAL STUDY ON THE HYDROGEN BONDING INTERACTIONS IN PARACETAMOL-WATER COMPLEXES
}

\author{
MEIFANG XU $U^{a, b}$, BOHAI ZHANG ${ }^{a}, Q I W A N G^{a}, Y U A N Y U A N^{a}, L E S U N^{a}, Z H E N G G U O H U A N G^{a 1 *}$ \\ ${ }^{a}$ Tianjin Key Laboratory of Structure and Performance for Functional Molecules; Key Laboratory of Inorganic-Organic Hybrid Functional Materials \\ Chemistry (Tianjin Normal University), Ministry of Education; College of Chemistry, Tianjin Normal University, Tianjin 300387, People's Republic of China \\ ${ }^{b}$ College of Mathematics Science, Tianjin Normal University, Tianjin 300387, People's Republic of China
}

\begin{abstract}
The paracetamol-water $\left(\mathrm{PA}-\mathrm{H}_{2} \mathrm{O}\right)$ complexes formed by hydrogen bonding interactions were investigated at the MP2/6-311++G(d,p) level. Six PA- $\mathrm{H}_{2} \mathrm{O}$ complexes possessing various types of hydrogen bonds (H-bonds) were characterized by geometries, energies, vibrational frequencies. Natural bond orbital (NBO), quantum theory of atoms in molecules (QTAIM) and the localized molecular orbital energy decomposition analysis (LMO-EDA) were performed to explore the nature of the hydrogen-bonding interactions in these complexes. The intramolecular H-bond formed between the methylene and carbonyl oxygen atom of paracetamol is retained in most of complexes. The H-bonds in PW1 and PW6 are stronger than other $\mathrm{H}$-bonds, moreover, the researches show that both the hydrogen bonding interaction and structural deformation play important roles for the relative stabilities of $\mathrm{PA}-\mathrm{H}_{2} \mathrm{O}$ complexes.
\end{abstract}

Keyword: paracetamol; hydrogen bonding interactions; natural bond orbital (NBO); quantum theory of atoms in molecules (QTAIM)

\section{INTRODUCTION}

Paracetamol (PA) is a widely used non-prescription drug, which can enhances the analgetic activity and reduces the nephrotoxicity ${ }^{1}$. A randomized controlled trial of chronic pain from osteoarthritis in adults found similar benefit from PA and diclofenac. In recommended doses, the side effects of PA are mild to non-existent, but acute overdoses of PA can cause potentially fatal kidney, brain and liver damage and, in rare individuals, a normal dose can do the same ${ }^{2-6}$. The risk may be heightened by chronic alcohol abuse. PA toxicity is the foremost cause of acute liver failure and accounts for most drug overdoses ${ }^{7-12}$

The infrared and Raman spectra of PA have been studied widely ${ }^{13-17}$ Joseph M. et al. have measured the resonant 2-photon ionization spectrum of jet-cooled PA, and analyzed the results in the light of theoretical calculations of the ground-state geometry and vibrational frequencies ${ }^{18}$. The complexes formed by PA with ethanol and acetone species have been studied by Y. Danten et al. ${ }^{19}$. Two nearly isoenergetic conformers were distinctly found in a supersonic molecular beam expansion and positively identified as the cis- and trans- isomers of PA by UV-UV hole-burning spectroscopy ${ }^{20}$

Weak interactions, especially hydrogen bonding interaction, play important roles in biological systems ${ }^{21-26}$. For example, hydrogen bonding interaction construct the structure of DNA and RNA (bonding between nitrogenous bases), the secondary structure of proteins (helix or pleated sheet) and the different branching patterns of sugar chains. For the pharmacological activity of PA, it is of importance to have information about the conformation of PA in solution, and hydrogen bonding interaction plays an important role on the conformations of PA since it is the major interaction in solution of PA. However, there is few literatures can be found so far. Therefore, we dedicated to study the hydrogen bonding interaction between $\mathrm{PA}$ and $\mathrm{H}_{2} \mathrm{O}$ solvent molecule by ab initio method, and we hope that this study will be helpful to the further study on the solvent effects of PA. It is important to note that not all theoretical methods are reliable for the description of hydrogen bond (H-bond) because it is usually weak. Compared with density functional theory (DFT), MP2 is too timeconsuming to apply to large biomolecular systems even with a medium-size basis set, however, it is a reliable method to descript $\mathrm{H}$-bond because it treats electron correlation well. Therefore, here MP2 was used to study the hydrogen bonding interactions in $\mathrm{PA}-\mathrm{H}_{2} \mathrm{O}$ complexes. The geometric parameters (bond length and bond angle) of $\mathrm{H}$-bond usually provide us preliminary information about the strength of $\mathrm{H}$-bond. However, more technical tools are required to elucidate the nature of $\mathrm{H}-$ bond in $\mathrm{PA}-\mathrm{H}_{2} \mathrm{O}$ complexes. The quantum theory of atoms in molecules (QTAIM) ${ }^{27,28}$, natural bond orbital (NBO) analysis ${ }^{29}$ and the localized molecular orbital energy decomposition analysis (LMO-EDA) 30 methods meet this requirements since they have been proved to be very useful tools in understanding of $\mathrm{H}-$ bond ${ }^{31-36}$. Therefore, ab initio calculations combined with QTAIM, NBO and LMO-EDA approaches were performed to investigate the hydrogen bonding interactions in $\mathrm{PA}-\mathrm{H}_{2} \mathrm{O}$ complexes.

\section{COMPUTATIONAL DETAILS}

The PA and water monomers were optimized at MP2/6-311++G (d,p) level , then the PA- $\mathrm{H}_{2} \mathrm{O}$ complexes were constructed starting from the most stable monomers and were fully optimized at the same level. Harmonic vibrational frequencies calculations were carried out to characterize the structures as minima and enable the evaluation of zero-point vibrational energies (ZPVE). To take into account the effects of the basis set superposition error (BSSE), the counterpoise corrections were implemented to insure that complexes and monomers are being computed with a consistent basis set. Then the interaction energies were calculated based on the ZPVE and BSSE corrections.

In order to analyze the properties of the H-bonds in complexes, QTAIM, NBO and LMO-EDA calculations were carried out. According to QTAIM, the first descriptor of $\mathrm{X}-\mathrm{H} \cdots \mathrm{Y} \mathrm{H}$-bond is the existence of the bond critical point (BCP) at the $\mathrm{H} \cdots \mathrm{Y}$ bond. Moreover, some descriptors at BCPs have been used widely to characterize the bonding between the atoms, such as the electron density $\left(\rho_{h}\right)$, the Laplacian of electron density $\left(\nabla^{2} \rho_{b}\right)$ and the total energy density $\left(H_{b}\right)^{37}$. Both $\rho_{b}$ and $\nabla^{2} \rho_{b}$ at the $\mathrm{H} \cdots \mathrm{Y}$ BCP are good measures of the strength of $\mathrm{H}$-bond. According to the criteria established by Koch and Popelier ${ }^{38}$, the $\nabla^{2} \rho_{b}$ should fall in the range of $0.024-0.139$ a.u., and the $\rho_{b}$ is within $0.002-0.034$ a.u.. Such criteria can used to distinguish hydrogen-bonding interactions from van der Waals interactions. The total electron energy density $\left(H_{b}\right)$ is the sum of the potential energy density $\left(V_{b}\right)$ and kinetic energy density $(G)$, which can also be used to characterize the interactions between atoms. The local priority of $V_{b}$ at the BCP results into a negative $H_{b}$, which means a partial covalent character is attributed to the $\mathrm{H}$-bonds. Meanwhile, the low and positive $\nabla^{2} \rho$ at the BCP means typical closed-shell interactions. Therefore, both $H_{b}$ and $\nabla^{2} \rho_{b}$ at the BCP can used to characterize the interaction ${ }^{39-42}$ : for very strong $\mathrm{H}-$ bonds, $\nabla^{2} \rho_{b}<0$ and $H_{b}<0$; for weak or medium-strength $\mathrm{H}-$ bonds, $\nabla^{2} \rho_{b}>0$ and $H_{b}>0$; for strong $\mathrm{H}-$ bonds, $\nabla^{2} \rho_{b}>0$ and $H_{b}<0$.

According to NBO theory ${ }^{43}$, the formation of $\mathrm{H}$-bond results into that electron density from the lone pair $n_{B}$ of the $\mathrm{H}$-acceptor delocalizes into the unfilled $\sigma_{X H}^{*}$ anti-bonding orbital of the $\mathrm{H}-$ donor. Therefore, the occupancy of the $\sigma_{X H}^{*}$ anti-bond orbital increases, which leads to that the $\mathrm{X}-\mathrm{H}$ bond is weakened and lengthened. The charge transfer (CT) effects between $n_{B}$ and $\sigma_{X H}^{*}$ is estimated by second-order perturbation energies $E(2)$, in other words, the $E(2)$ lowering is responsible for the orbital interaction of $\mathrm{H}$-bond, the larger $E(2)$ values correspond to stronger $\mathrm{CT}$ interaction occurred in the $\mathrm{H}-$ bond. In LMO-EDA, total interaction energy $\Delta E_{\mathrm{MP} 2}$ is decomposed into five terms: electrostatic energy $\left(\Delta E_{\mathrm{ele}}\right)$, exchange energy $\left(\Delta E_{\mathrm{ex}}\right)$, repulsion energy $\left(\Delta E_{\mathrm{rep}}\right)$, polarization energy $\left(\Delta \mathrm{E}_{\mathrm{pol}}\right)$ and dispersion energy $\left(\Delta E_{\text {diss }}\right)$. The ab initio and NBO calculations were carried out using Gaussian $09^{44}$, QTAIM analysis was performed using the wave functions obtained at the MP2/6-311++G(d,p) level by AIM $2000^{45}$, and the LMO-EDA was implement at the same level using the Gamess program ${ }^{46}$. 


\section{RESULTS AND DISCUSSION}

The PA and water monomers were optimized at the MP2/6-311++G(d,p) level, and the molecular graphs are presented in Figure 1. As shown in Figure 1, water molecule can donate/accept proton to form $\mathrm{H}$-bond, in which the hydroxyl and oxygen atom act as $\mathrm{H}$-donor/acceptor, respectively. PA has several possible proton-donor/acceptor sites to form $\mathrm{H}$-bonds. The imino group in the benzene ring and the phenolic hydroxyl are the main $\mathrm{H}$-donor sites of PA, while the methylene can also form weak $\mathrm{H}$-bonds with water in some complexes. The main $\mathrm{H}$-acceptors of PA are the oxygen atoms of the hydroxyl and carbonyl groups. Moreover, the oxygen atom of the carbonyl groups usually accepts one proton to form intramolecular $\mathrm{H}-$-bond with the methylene.

\subsection{Structures}

All molecular graphs of optimized $\mathrm{PA}-\mathrm{H}_{2} \mathrm{O}$ complexes are shown in Figure 2, and the structural parameters of $\mathrm{H}$-bonds are listed in Table 1. As shown in Figure 2, different types of

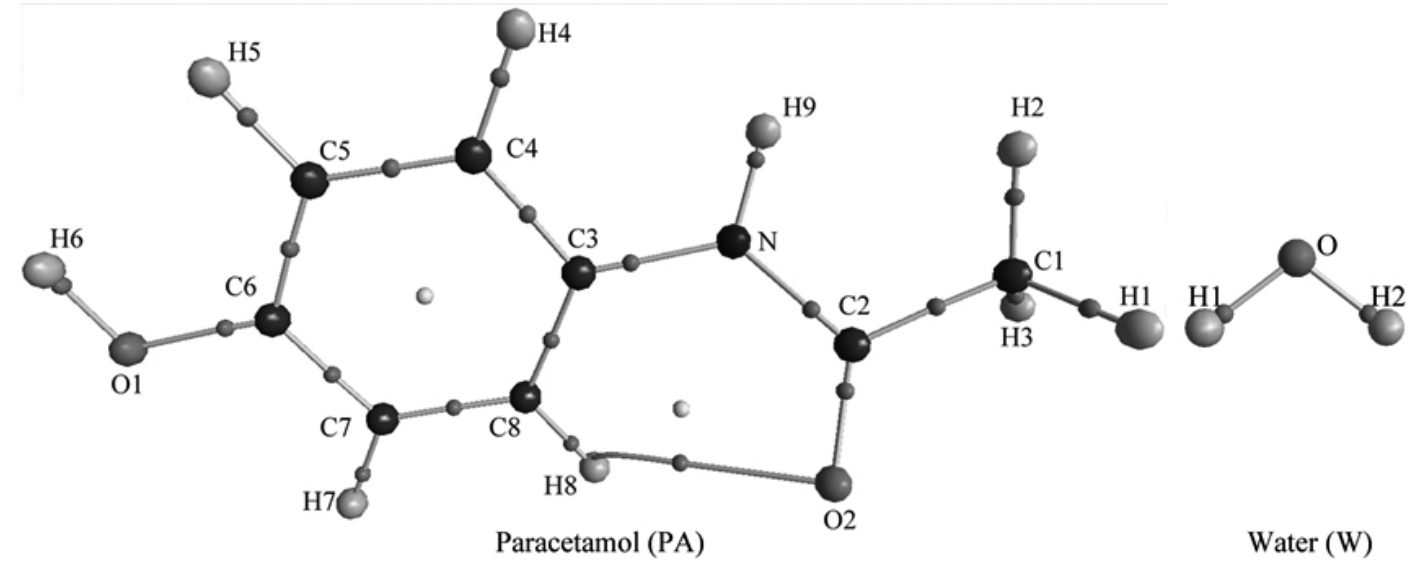

Figure 1. Molecular graphs of paracetamol (PA) and water (W) monomers. Large circles correspond to attractors attributed to atomic positions: white, H; blue, N; gray, C; red, O. Small circles are attributed to critical points: red, bond critical point; yellow, ring critical point.

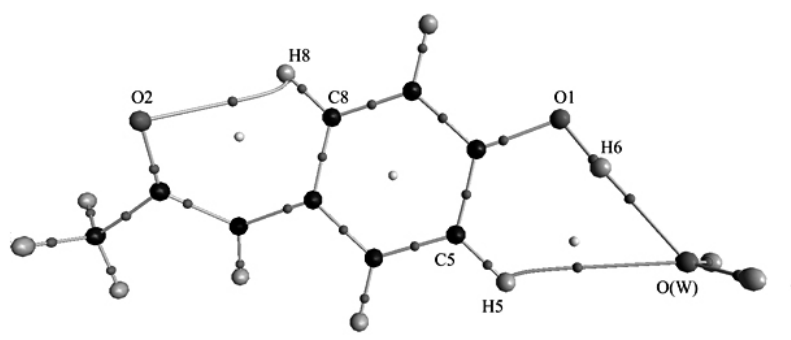

PW1

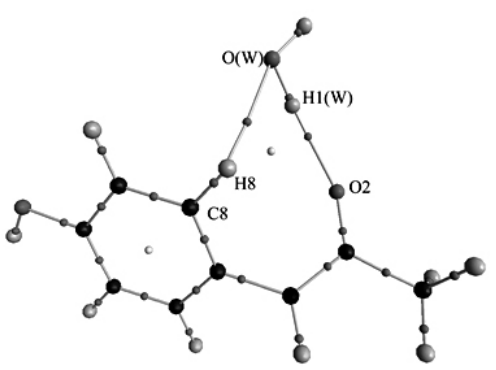

PW3

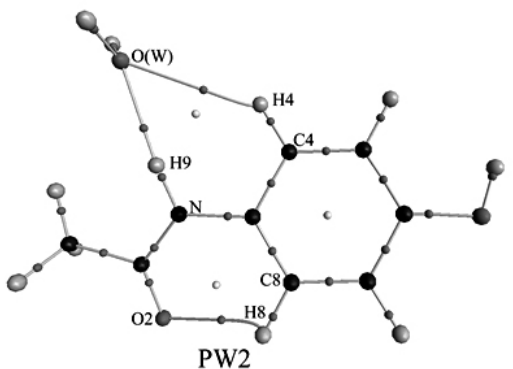

PW2

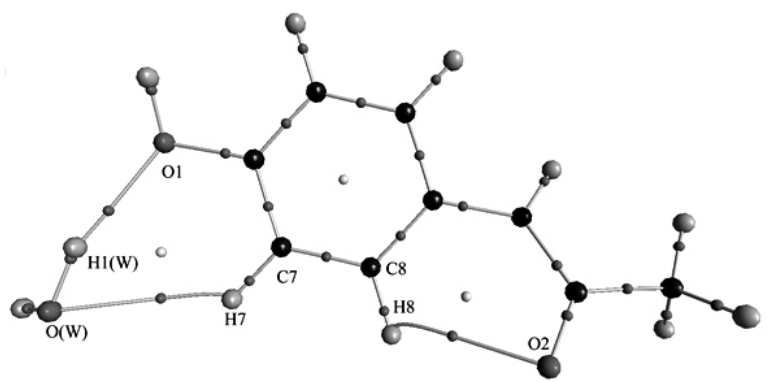

PW4

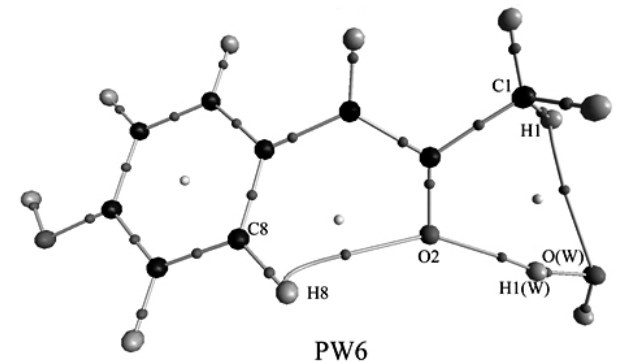

PW6

PW5

Figure 2. Molecular graphs of $\mathrm{PA}-\mathrm{H}_{2} \mathrm{O}$ complexes. Large circles correspond to attractors attributed to atomic positions: white, H; blue, N; gray, C; red, O. Small circles are attributed to critical points: red, bond critical point; yellow, ring critical point. 
Table 1. Structural parameters (bond lengths in $\AA$, angles in degrees) of $\mathrm{H}-$ bonds in $\mathrm{PA}-\mathrm{H}_{2} \mathrm{O}$ complexes calculated at the MP2/6-311++G(d,p) level.

\begin{tabular}{|c|c|c|c|c|c|c|}
\hline complex & $\mathrm{H}-$-bond $^{\mathrm{a}}$ & $\mathrm{R}_{\mathrm{X}-\mathrm{H}}$ & $\Delta \mathrm{R}_{\mathrm{X}-\mathrm{H}}^{\mathrm{b}}$ & $\mathrm{R}_{\mathrm{H} \cdots \mathrm{Y}}$ & $\delta \mathrm{R}_{\mathrm{H} \cdots \mathrm{Y}}$ & $\theta_{\mathrm{X}-\mathrm{H} \cdots \mathrm{Y}}$ \\
\hline \multirow[t]{3}{*}{ PW1 } & $\mathrm{C} 8 \mathrm{H} 8^{\mathrm{PA}} \cdots \mathrm{O} 2^{\mathrm{PA}}$ & 1.083 & 0.001 & 2.392 & 0.328 & 109.4 \\
\hline & $\mathrm{C} 5 \mathrm{H} 5^{\mathrm{PA} \cdots} \cdot \mathrm{O}^{\mathrm{W}}$ & 1.087 & -0.001 & 2.681 & 0.039 & 128.4 \\
\hline & $\mathrm{O} 1 \mathrm{H} 6^{\mathrm{PA} \cdots \mathrm{O}^{\mathrm{W}}}$ & 0.970 & 0.008 & 1.878 & 0.842 & 177.5 \\
\hline \multirow[t]{3}{*}{ PW2 } & $\mathrm{C} 8 \mathrm{H} 8^{\mathrm{PA}} \cdots \mathrm{O} 2^{\mathrm{PA}}$ & 1.082 & -0.001 & 2.269 & 0.451 & 115.2 \\
\hline & $\mathrm{C} 4 \mathrm{H} 4^{\mathrm{PA}} \cdots \mathrm{O}^{\mathrm{W}}$ & 1.087 & -0.001 & 2.695 & 0.025 & 135.7 \\
\hline & $\mathrm{NH}^{\mathrm{PA}} \cdots \mathrm{O}^{\mathrm{W}}$ & 1.014 & 0.005 & 2.032 & 0.688 & 173.9 \\
\hline \multirow[t]{2}{*}{ PW3 } & $\mathrm{C} 8 \mathrm{H} 8^{\mathrm{PA}} \cdots \mathrm{O}^{\mathrm{W}}$ & 1.084 & 0.002 & 2.479 & 0.241 & 120.3 \\
\hline & $\mathrm{OH} 1^{\mathrm{W}} \cdots \mathrm{O} 2^{\mathrm{PA}}$ & 0.968 & 0.008 & 1.930 & 0.790 & 166.1 \\
\hline \multirow{3}{*}{ PW4 } & $\mathrm{C} 8 \mathrm{H} 8^{\mathrm{PA}} \cdots \mathrm{O} 2^{\mathrm{PA}}$ & 1.082 & 0.000 & 2.347 & 0.373 & 111.0 \\
\hline & $\mathrm{C} 7 \mathrm{H}^{\mathrm{PA}} \cdots \mathrm{O}^{\mathrm{W}}$ & 1.086 & 0.000 & 2.537 & 0.183 & 135.4 \\
\hline & $\mathrm{OH} 1^{\mathrm{W}} \cdots \mathrm{O} 1^{\mathrm{PA}}$ & 0.965 & 0.005 & 1.985 & 0.735 & 162.0 \\
\hline PW5 & $\mathrm{OH} 1^{\mathrm{W}} \cdots \mathrm{O} 2^{\mathrm{PA}}$ & 0.967 & 0.007 & 2.017 & 0.703 & 168.8 \\
\hline \multirow[t]{3}{*}{ PW6 } & $\mathrm{C} 8 \mathrm{H} 8^{\mathrm{PA}} \cdots \mathrm{O} 2^{\mathrm{PA}}$ & 1.083 & 0.001 & 2.417 & 0.303 & 107.0 \\
\hline & $\mathrm{OH} 1^{\mathrm{W}} \cdots \mathrm{O} 2^{\mathrm{PA}}$ & 0.970 & 0.011 & 1.885 & 0.835 & 165.1 \\
\hline & $\mathrm{C} 1 \mathrm{H} 1^{\mathrm{PA} \cdots \mathrm{O}^{\mathrm{W}}}$ & 1.091 & -0.002 & 2.624 & 0.096 & 117.0 \\
\hline \multirow[t]{7}{*}{ PA } & $\mathrm{C} 8 \mathrm{H} 8$ & 1.082 & & 2.367 & 0.353 & 110.1 \\
\hline & $\mathrm{C} 5 \mathrm{H} 5$ & 1.088 & & & & \\
\hline & O1H6 & 0.962 & & & & \\
\hline & $\mathrm{C} 4 \mathrm{H} 4$ & 1.088 & & & & \\
\hline & NH9 & 1.010 & & & & \\
\hline & $\mathrm{C} 7 \mathrm{H} 7$ & 1.086 & & & & \\
\hline & $\mathrm{C} 1 \mathrm{H} 1$ & 1.093 & & & & \\
\hline Water & $\mathrm{OH}$ & 0.960 & & & & \\
\hline
\end{tabular}

a Superscript "PA" denotes paracetamol and superscript "W" denotes $\mathrm{H}_{2} \mathrm{O}$

${ }^{\mathrm{b}} \Delta \mathrm{R}_{\mathrm{X}-\mathrm{H}}=\mathrm{R}_{\mathrm{X}-\mathrm{H}}$ (complexes) $-\mathrm{R}_{\mathrm{X}-\mathrm{H}}$ (free monomer)

$\mathrm{H}$-bonds are formed in PA- $\mathrm{H}_{2} \mathrm{O}$ complexes. According to QTAIM, the $\mathrm{H}$-bond, including inter- or intramolecular $\mathrm{H}$-bonds, is characterized by the BCPs between $\mathrm{H}-$ donor $(\mathrm{X}-\mathrm{H})$ and $\mathrm{H}$-acceptor $(\mathrm{Y})$, and ring structure formed by multiple $\mathrm{H}$-bonds is characterized by a ring critical point (RCP). The shorter distance between the RCP and corresponding BCP means less stability of the $\mathrm{H}-$ bond ${ }^{47-50}$. As a note, the RCP at the center of the ring of benzene has nothing to do with $\mathrm{H}$-bond. As shown in Figs. 1 and 2, one intramolecular $\mathrm{C} 8 \mathrm{H} 8^{\mathrm{PA}} \cdots \mathrm{O} 2^{\mathrm{PA}} \mathrm{H}-$ bond formed between the methylene and the oxygen atom can be found in PA monomer, which is retained in all $\mathrm{PA}-\mathrm{H}_{2} \mathrm{O}$ complexes except PW3 and PW5.

As shown in Fig. 2, PW3 have two $\mathrm{H}-$ bonds, but PW5 have one $\mathrm{H}-$ bond. The $\mathrm{C} 8 \mathrm{H} 8^{\mathrm{PA}} \cdots \mathrm{O} 2^{\mathrm{PA}}$ intramolecular $\mathrm{H}$-bond in $\mathrm{PW} 3$ is replaced by two intermolecular $\mathrm{H}$-bonds, in which water monomer acts as $\mathrm{H}$-donor and $\mathrm{H}$-acceptor simultaneously. Similarly, the $\mathrm{C} 8 \mathrm{H} 8^{\mathrm{PA}} \cdots \mathrm{O}^{\mathrm{PA}}$ intramolecular $\mathrm{H}-$ bond in PW5 is also replaced by one intermolecular $\mathrm{H}$-bond formed between the hydroxyl of water moiety donating one proton to oxygen atom of the carbonyl groups in PA moiety. Therefore, it can learn that the serious structura deformations occurred in PW3 and PW5. In addition, it worth noting that there seems to be one $\pi \mathrm{H}$-bond formed between the hydroxyl of water and the benzene ring of PA monomer, and the distance between the hydrogen atom and the center of the benzene ring is $2.738 \AA$. Unfortunately, such $\pi \mathrm{H}$-bond cannot be characterized by QTAIM directly. Except for the $\mathrm{C} 8 \mathrm{H} 8^{\mathrm{PA}} \cdots \mathrm{O} 2^{\mathrm{PA}}$ intramolecular $\mathrm{H}$-bond, other complexes have two intermolecular $\mathrm{H}$-bonds The oxygen atom of water moiety accepts two protons from the hydroxyl and methylene of PA simultaneously to form one bifurcated H-bond in PW1. Another bifurcated $\mathrm{H}-$ bond can be found in PW2, which is formed by the oxygen atom of water moiety accepts two protons from the hydroxyl and imino of PA simultaneously. For the PW4 and PW6 complexes, two intermolecular $\mathrm{H}$-bonds are formed, in which water monomer acts as $\mathrm{H}$-donor and $\mathrm{H}-$ acceptor, respectively.

The change $\left(\Delta \mathrm{R}_{\mathrm{X} H}\right)$ of the $\mathrm{X}-\mathrm{H}$ bond with respect to the corresponding
$\mathrm{X}-\mathrm{H}$ bond in free monomers (PA or water) reflects the nature of $\mathrm{H}-$ bond, the elongation of the $\mathrm{X}-\mathrm{H}$ bond corresponds to red-shifting $\mathrm{H}-$ bond, while the shortening of the $\mathrm{X}-\mathrm{H}$ bond represents blue-shifting one. In addition, the distance of the $\mathrm{H} \cdots \mathrm{Y}$ bond reflects the strength of the hydrogen bonding interaction as well. As shown in Table 1 , for most of the complexes, the $\Delta \mathrm{R}_{\mathrm{x}}$ of the $\mathrm{H}$-bonds taking methylene as $\mathrm{H}$-donors are negative or remain little changes, which indicates that they are very weak $\mathrm{H}$-bonds. All other $\mathrm{H}$-bonds have positive $\Delta \mathrm{R}_{\mathrm{X}-\mathrm{H}}$ values and are red-shifting ones. The largest $\Delta \mathrm{R}_{\mathrm{X}-\mathrm{H}}$

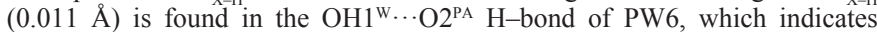
that it is the strongest intermolecular $\mathrm{H}$-bond. It is worth noting that another intermolecular $\mathrm{H}-$-bond $\left(\mathrm{O} 1 \mathrm{H}^{\mathrm{PA}} \cdots \mathrm{O}^{\mathrm{W}}\right)$ in $\mathrm{PW} 1$ is also strong, considering its short $R_{\mathrm{H} Y \mathrm{Y}}(1.878 \AA)$. However, its $\Delta \mathrm{R}_{\mathrm{X} H}(0.008 \AA)$ is smaller than that of the $\mathrm{OH} 1^{\mathrm{w}} \cdots \mathrm{O} 2^{\mathrm{PA}} \mathrm{H}$-bond in PW6. Therefore, for such case, $\Delta \mathrm{R}_{\mathrm{X}-\mathrm{H}}$ is not the unique technical means to estimate the strength of the $\mathrm{H}$-bond, while $R_{\mathrm{H}}$ is an alternative choice. As shown in Table 1, the shortest of $R_{\mathrm{H} \ldots \mathrm{Y}}$ is 1.878 $\AA$ of the intermolecular $\mathrm{O} 1 \mathrm{H}^{\mathrm{PA}} \cdots \mathrm{O}^{\mathrm{W}} \mathrm{H}$-bond in $\mathrm{PW} 1$, which seems to be the strongest $\mathrm{H}$-bond. Of course, another intermolecular $\mathrm{H}$-bond in PW6,

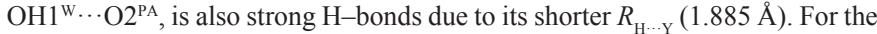
$\mathrm{H}$-bonds in which methylene acts as $\mathrm{H}$-donor in some PA complexes (PW1, PW2, PW4 and PW6), the $R$ values are small and close to the sum of the van der Waals radii of the $\mathrm{H}$ and $\mathrm{Y}$ atoms. Therefore, from a structural viewpoint, the interaction between the methylene and $\mathrm{Y}$ atom is very weak and has partial van der Waals character.

3.2 Vibrational Frequencies

The harmonic vibrational frequencies of $\mathrm{H}-$ bonds in $\mathrm{PA}-\mathrm{H}_{2} \mathrm{O}$ complexes and monomers as well as their shifts calculated at the MP2/6-311++G(d,p) level are listed in Table 2. The shift $\left(\Delta v_{\mathrm{X}-\mathrm{H}}\right)$ of the $\mathrm{X}-\mathrm{H}$ stretching vibrational frequency is one of the main fingerprints of $\mathrm{H}$-bonds. It is generally accepted that the $\mathrm{X}-\mathrm{H}$ bond is weakened due to the formation of an $\mathrm{H}-$ bond, which lead to the red shift of $v_{\mathrm{X}-\mathrm{H}^{*}}$. The larger the $\Delta v_{\mathrm{X}-\mathrm{H}}$ is, the stronger the $\mathrm{H}-$ bond is. However, it is 
Table 2. The $\mathrm{X}-\mathrm{H}$ stretching vibrational frequencies (strength) of $\mathrm{H}-$ bonds in both $\mathrm{PA}-\mathrm{H}_{2} \mathrm{O}$ complexes and monomers.

\begin{tabular}{|c|c|c|c|}
\hline complex & $\mathrm{H}$-bond & $v_{X-H}^{a}$ & $\Delta v_{\mathrm{X}-\mathrm{H}}$ \\
\hline \multirow{3}{*}{ PW1 } & $\mathrm{C} 8 \mathrm{H} 8^{\mathrm{PA} \cdots \mathrm{O} 2^{\mathrm{PA}}}$ & $3263.2(0, \mathrm{~s})^{\mathrm{b}}$ & -4.2 \\
\hline & $\mathrm{C} 5 \mathrm{H} 5^{\mathrm{PA} \cdots} \mathrm{O}^{\mathrm{W}}$ & $3218.5(2, \mathrm{~s})^{\mathrm{c}}$ & 13.4 \\
\hline & $\mathrm{O} 1 \mathrm{H}^{\mathrm{PA}} \cdots \mathrm{O}^{\mathrm{W}}$ & $3724.8(684)^{\mathrm{d}}$ & -151.2 \\
\hline \multirow[t]{3}{*}{ PW2 } & $\mathrm{C} 8 \mathrm{H} 8^{\mathrm{PA} \cdots \mathrm{O} 2^{\mathrm{PA}}}$ & $3273.7(3, \mathrm{~s})^{\mathrm{b}}$ & 6.3 \\
\hline & $\mathrm{C} 4 \mathrm{H} 4^{\mathrm{PA}} \cdots \mathrm{O}^{\mathrm{W}}$ & $3215.2(2, \mathrm{~s})^{\mathrm{e}}$ & 10.1 \\
\hline & $\mathrm{NH}^{\mathrm{PA} \cdots \mathrm{O}^{\mathrm{W}}}$ & $3588.2(237)^{\mathrm{d}}$ & -71 \\
\hline \multirow[t]{2}{*}{ PW3 } & $\mathrm{C} 8 \mathrm{H} 8^{\mathrm{PA} \cdots} \mathrm{O}^{\mathrm{W}}$ & $3254.6(2, \mathrm{~s})^{\mathrm{b}}$ & -12.8 \\
\hline & $\mathrm{OH} 1^{\mathrm{W}} \cdots \mathrm{O} 2^{\mathrm{PA}}$ & $3962.6(107$, as $), 3780.2(272, \mathrm{~s})$ & $-40,-104.1$ \\
\hline \multirow[t]{3}{*}{ PW4 } & $\mathrm{C} 8 \mathrm{H} 8^{\mathrm{PA}} \cdots \mathrm{O} 2^{\mathrm{PA}}$ & $3269.7(2, \mathrm{~s})^{\mathrm{b}}$ & 2.3 \\
\hline & $\mathrm{C} 7 \mathrm{H} 7^{\mathrm{PA}} \cdots \mathrm{O}^{\mathrm{W}}$ & $3229.8(4, a s)^{\mathrm{f}}$ & 2.3 \\
\hline & $\mathrm{OH} 1^{\mathrm{W}} \cdots \mathrm{O} 1^{\mathrm{PA}}$ & $3969.4(138$, as $), 3816.4(194, \mathrm{~s})^{\mathrm{g}}$ & $-33.2,-67.9$ \\
\hline PW5 & $\mathrm{OH} 1^{\mathrm{W}} \cdots \mathrm{O} 2^{\mathrm{PA}}$ & $3942.2(46$, as $), 3799.0(169, \mathrm{~s})$ & $-60.4,-85.3$ \\
\hline \multirow[t]{3}{*}{ PW6 } & $\mathrm{C} 8 \mathrm{H} 8^{\mathrm{PA}} \cdots \mathrm{O} 2^{\mathrm{PA}}$ & $3262.7(0, s)^{b}$ & -4.7 \\
\hline & 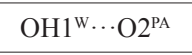 & $3961.7(108$, as $), 3710.5(580, \mathrm{~s})^{\mathrm{h}}$ & $-40.9,-173.8$ \\
\hline & $\mathrm{C} 1 \mathrm{H} 1^{\mathrm{PA} \cdots} \mathrm{O}^{\mathrm{W}}$ & $3196.6(3, \mathrm{as})^{\mathrm{i}}, 3086.6(7, \mathrm{~s})^{\mathrm{j}}$ & $18.3,0.4$ \\
\hline \multirow[t]{7}{*}{ PA } & $\mathrm{C} 8 \mathrm{H} 8$ & $3267.4(1, \mathrm{~s})^{\mathrm{b}}$ & \\
\hline & $\mathrm{C} 5 \mathrm{H} 5$ & $3205 \cdot 1(8, \mathrm{~s})^{\mathrm{c}}$ & \\
\hline & O1H6 & $3876.0(77)$ & \\
\hline & $\mathrm{C} 4 \mathrm{H} 4$ & $3205.1(8, \mathrm{~s})^{\mathrm{b}}$ & \\
\hline & NH9 & $3659.2(30)$ & \\
\hline & $\mathrm{C} 7 \mathrm{H} 7$ & $3227.5(2, \mathrm{as})^{\mathrm{f}}$ & \\
\hline & $\mathrm{C} 1 \mathrm{H} 1$ & $3178.3(9, a \mathrm{as})^{\mathrm{i}}, 3086.2(8, \mathrm{~s})^{\mathrm{j}}$ & \\
\hline Water & $\mathrm{OH}$ & $4002.6(63$, as $), 3884.3(13, \mathrm{~s})$ & \\
\hline
\end{tabular}

a All frequencies are in $\mathrm{cm}^{-1}$ and the strengths are in $\mathrm{km} \cdot \mathrm{mol}^{-1}$. "as" denotes the asymmetric stretching vibration mode, and "s" denotes the symmetric stretching vibration mode.

${ }^{\mathrm{b}}$ Mixing occurs among the $\mathrm{C} 7 \mathrm{H} 7$ and $\mathrm{C} 5 \mathrm{H} 5$ stretching vibration modes

${ }^{c}$ Mixing occurs among the $\mathrm{C} 8 \mathrm{H} 8$ and $\mathrm{C} 4 \mathrm{H} 4$ stretching vibration modes

Mixed with symmetric $\mathrm{H}-\mathrm{O}-\mathrm{H}$ stretching vibration mode of free water molecule slightly.

${ }^{e}$ Mixing occurs among the $\mathrm{C} 5 \mathrm{H} 5, \mathrm{C} 7 \mathrm{H} 7$ and $\mathrm{C} 8 \mathrm{H} 8$ stretching vibration modes

${ }^{\mathrm{f}}$ Mixing occurs among the $\mathrm{C} 8 \mathrm{H} 8$ and $\mathrm{C} 4 \mathrm{H} 4$ stretching vibration modes

${ }^{\mathrm{g}}$ Slight mixing with O1H6 stretching vibration modes

${ }^{\text {h }}$ Slight mixing with NH9 stretching vibration modes

${ }^{i}$ Strong mixing with asymmetric $\mathrm{H} 3-\mathrm{C} 2-\mathrm{H} 2$ stretching vibration modes

${ }^{j}$ Strong mixing with symmetric $\mathrm{H} 3-\mathrm{C} 2-\mathrm{H} 2$ stretching vibration modes

hard to calculate the $\Delta v_{\mathrm{X}-\mathrm{H}}$ when the $\mathrm{X}-\mathrm{H}$ stretching vibrational mode mixes with other vibrational modes. For example, the mixture between $\mathrm{C} 1 \mathrm{H} 1$ and asymmetric/symmetric $\mathrm{H} 3-\mathrm{C} 2-\mathrm{H} 2$ stretching vibration modes in free PA molecule are calculated to be 3178.3 and $3086.2 \mathrm{~cm}^{-1}$, respectively, so two $\Delta v_{\mathrm{X}-\mathrm{H}}$ values may be given for such $\mathrm{H}$-bonds involving $\mathrm{C} 1 \mathrm{H} 1$ as $\mathrm{H}$-donor. Similar things are also seen for $\mathrm{PA}-\mathrm{H}_{2} \mathrm{O}$ complexes. Taking PW4 as an example, the symmetric stretching vibrational mode of $\mathrm{OH} 1^{\mathrm{W} \cdots \mathrm{O}} 1^{\mathrm{PA}}$ mixes with $\mathrm{O} 1 \mathrm{H} 6$, and the values of $\Delta v_{\mathrm{X}}$ with respect to the corresponding stretching vibration modes in free $\mathrm{H}_{2} \mathrm{O}$ molecule are calculated to be -33.2 and $-67.9 \mathrm{~cm}^{-1}$, respectively. As shown in Table 2, the largest red-shift value of $-173.8 \mathrm{~cm}^{-1}$ is found for the

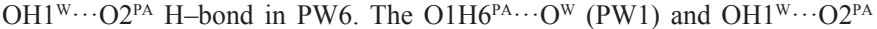
(PW3) H-bonds have large red-shifts of more than $-100 \mathrm{~cm}^{-1}$, so the strengths

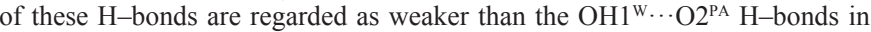
PW6 and stronger than other red-shifted $\mathrm{H}$-bonds. Other intermolecular $\mathrm{H}-$ bonds in the $\mathrm{PA}-\mathrm{H}_{2} \mathrm{O}$ complexes are weaker since their absolute values of $\Delta v_{\mathrm{XH}}$ are less than $100 \mathrm{~cm}^{-1}$. There are seven blue-shifted H-bonds which have positive shift values of $\Delta v_{\mathrm{X}-\mathrm{H}}$, moreover, they are usually weaker than the red-shifted ones and a partial dispersion character is attributed to them. However, the small $\Delta v_{\mathrm{X}-\mathrm{H}}$ of the intramolecular $\mathrm{C} 8 \mathrm{H} 8^{\mathrm{PA} \cdots} \mathrm{O}^{\mathrm{PA}} \mathrm{H}-$ bond in $\mathrm{PA}-$
$\mathrm{H}_{2} \mathrm{O}$ complexes does not mean that it is also very weak, as it originally existed in the free PA molecule.

3.3 Bonding analyses

The electronic topological properties at the $\mathrm{H}^{\cdots} \mathrm{Y}$ BCPs of $\mathrm{H}$-bonds, including the electron density $(\rho)$, the Laplacian of the electron density $\left(\nabla^{2} \rho_{b}\right)$, the kinetic energy density $\left(G_{b}\right)$, the potential energy density $\left(V_{b}\right)$, and the total electron energy density $\left(H_{b}\right)$, for all of the complexes and monomer are listed in Table 3. As shown in Table 3, among all PA- $\mathrm{H}_{2} \mathrm{O}$ complexes and PA monomer, both the $H_{b}$ and $\nabla^{2} \rho_{b}$ of all $\mathrm{H}$-bonds are positive and fall in the ranges proposed by Popelier, thus they are considered as weak or medium $\mathrm{H}-$ bonds. Especially, for the $\mathrm{H}$-bonds taking methylene as $\mathrm{H}-$ donor, both $\rho_{b}$ and $\nabla^{2} \rho_{b}$ are close to the lower limit of criteria proposed by Popelier, which shows that they are very weak and partial dispersion character is attributed to them. Moreover, the $\mathrm{H}$-bonds involving the hydroxyl as $\mathrm{H}$-donors are stronger than other ones due to larger $\rho_{b}$ and $\nabla^{2} \rho_{b}$. Especially, for the $\mathrm{OH} 1^{\mathrm{W} \cdots \mathrm{O} 2^{\mathrm{PA}}}$ (PW6) and $\mathrm{O}_{1 \mathrm{H}} 6^{\mathrm{PA} \cdots \mathrm{O}^{\mathrm{W}}}$ (PW1) $\mathrm{H}$-bonds, both $\rho_{b}$ and $\nabla^{2} \rho_{b}$ of them are the largest among all $\mathrm{H}$-bonds, which indicates that they are the two strongest $\mathrm{H}$-bonds. 
Table 3. The electron density $\left(\rho_{b}\right)$ and its Laplacian $\left(\nabla^{2} \rho_{b}\right)$, total electron energy density $\left(H_{b}\right)$, potential energy density $\left(V_{b}\right)$ and Lagrangian form of kinetic energy density $\left(G_{b}\right)$ in a.u. at $\mathrm{H} \cdots \mathrm{Y}$ BCPs of $\mathrm{H}$-bonds in PA- $\mathrm{H}_{2} \mathrm{O}$ complexes obtained by QTAIM analysis.

\begin{tabular}{|c|c|c|c|c|c|c|}
\hline complex & H-bond & $\rho_{b}$ & $\nabla^{2} \rho_{b}$ & $H_{b}$ & $V_{b}$ & $G_{b}$ \\
\hline \multirow[t]{3}{*}{ PW1 } & $\mathrm{C} 8 \mathrm{H} 8^{\mathrm{PA}} \cdots \mathrm{O} 2^{\mathrm{PA}}$ & 0.01322 & 0.05192 & 0.00174 & -0.00951 & 0.01124 \\
\hline & $\mathrm{C} 5 \mathrm{H} 5^{\mathrm{PA} \cdots \mathrm{O}^{\mathrm{W}}}$ & 0.00621 & 0.02321 & 0.00085 & -0.00411 & 0.00496 \\
\hline & $\mathrm{O} 1 \mathrm{H} 6^{\mathrm{PA} \cdots \mathrm{O}^{\mathrm{W}}}$ & 0.02542 & 0.11139 & 0.00309 & -0.02166 & 0.02476 \\
\hline \multirow[t]{3}{*}{ PW2 } & $\mathrm{C} 8 \mathrm{H} 8^{\mathrm{PA} \cdots \mathrm{O} 2^{\mathrm{PA}}}$ & 0.01602 & 0.06367 & 0.00213 & -0.01165 & 0.01379 \\
\hline & $\mathrm{C} 4 \mathrm{H} 4^{\mathrm{PA}} \cdots \mathrm{O}^{\mathrm{W}}$ & 0.00603 & 0.02148 & 0.00072 & -0.00393 & 0.00465 \\
\hline & $\mathrm{NH} 9^{\mathrm{PA}} \cdots \mathrm{O}^{\mathrm{W}}$ & 0.01826 & 0.08051 & 0.00318 & -0.01377 & 0.01695 \\
\hline \multirow[t]{2}{*}{ PW3 } & $\mathrm{C} 8 \mathrm{H} 8^{\mathrm{PA}} \cdots \mathrm{O}^{\mathrm{W}}$ & 0.00855 & 0.03728 & 0.00167 & -0.00598 & 0.00765 \\
\hline & $\mathrm{OH} 1^{\mathrm{w}} \cdots \mathrm{O} 2^{\mathrm{PA}}$ & 0.02097 & 0.09923 & 0.00381 & -0.01719 & 0.02100 \\
\hline \multirow[t]{3}{*}{ PW4 } & $\mathrm{C} 8 \mathrm{H} 8^{\mathrm{PA}} \cdots \mathrm{O} 2^{\mathrm{PA}}$ & 0.01419 & 0.05604 & 0.00188 & -0.01024 & 0.01213 \\
\hline & $\mathrm{C} 7 \mathrm{H} 7^{\mathrm{PA}} \cdots \mathrm{O}^{\mathrm{W}}$ & 0.00764 & 0.02881 & 0.00109 & -0.00503 & 0.00612 \\
\hline & $\mathrm{OH} 1^{\mathrm{w}} \cdots \mathrm{O} 1^{\mathrm{PA}}$ & 0.01970 & 0.08973 & 0.00345 & -0.01554 & 0.01898 \\
\hline PW5 & $\mathrm{OH} 1^{\mathrm{w}} \cdots \mathrm{O} 2^{\mathrm{PA}}$ & 0.01834 & 0.07905 & 0.00299 & -0.01378 & 0.01677 \\
\hline \multirow[t]{3}{*}{ PW6 } & $\mathrm{C} 8 \mathrm{H} 8^{\mathrm{PA}} \cdots \mathrm{O} 2^{\mathrm{PA}}$ & 0.01293 & 0.05165 & 0.00174 & -0.00943 & 0.01117 \\
\hline & $\mathrm{OH} 1^{\mathrm{w}} \cdots \mathrm{O} 2^{\mathrm{PA}}$ & 0.02609 & 0.11010 & 0.00276 & -0.02200 & 0.02476 \\
\hline & $\mathrm{C} 1 \mathrm{H} 1^{\mathrm{PA}} \cdots \mathrm{O}^{\mathrm{W}}$ & 0.00662 & 0.02804 & 0.00122 & -0.00458 & 0.00579 \\
\hline $\mathrm{PA}$ & $\mathrm{C} 8 \mathrm{H} 8^{\mathrm{PA}} \cdots \mathrm{O} 2^{\mathrm{PA}}$ & 0.01379 & 0.05435 & 0.00182 & -0.00994 & 0.01176 \\
\hline
\end{tabular}

Table 4. The second-order perturbation energies $E(2)$ (in $\mathrm{kcal} \cdot \mathrm{mol}^{-1}$ ) of the $\mathrm{H}-$ bonds in $\mathrm{PA}-\mathrm{H}_{2} \mathrm{O}$ complexes obtained by NBO analysis.

\begin{tabular}{|c|c|c|}
\hline complex & H-bond & $E(2)^{\mathrm{a}}$ \\
\hline \multirow[t]{2}{*}{ PW1 } & $\mathrm{C} 5 \mathrm{H} 5^{\mathrm{PA}} \cdots \mathrm{O}^{\mathrm{W}}$ & $0.38(0.11)$ \\
\hline & $\mathrm{O} 1 \mathrm{H} 6^{\mathrm{PA}} \cdots \mathrm{O}^{\mathrm{W}}$ & $0.07(11.30)$ \\
\hline \multirow[t]{3}{*}{ PW2 } & $\mathrm{C} 8 \mathrm{H} 8^{\mathrm{PA}} \cdots \mathrm{O} 2^{\mathrm{PA}}$ & 0.51 \\
\hline & $\mathrm{C} 4 \mathrm{H} 4^{\mathrm{PA}} \cdots \mathrm{O}^{\mathrm{W}}$ & $0.44(0.14)$ \\
\hline & $\mathrm{NH} 9^{\mathrm{PA}} \cdots \mathrm{O}^{\mathrm{W}}$ & $0.05(7.17)$ \\
\hline \multirow[t]{2}{*}{ PW3 } & $\mathrm{C} 8 \mathrm{H} 8^{\mathrm{PA}} \cdots \mathrm{O}^{\mathrm{W}}$ & $0.06(0.39)$ \\
\hline & $\mathrm{OH} 1^{\mathrm{W}} \cdots \mathrm{O} 2^{\mathrm{PA}}$ & $3.60(1.66)$ \\
\hline \multirow[t]{2}{*}{ PW4 } & $\mathrm{C} 7 \mathrm{H} 7^{\mathrm{PA}} \cdots \mathrm{O}^{\mathrm{W}}$ & $0.09(0.75)$ \\
\hline & $\mathrm{OH} 1^{\mathrm{w}} \cdots \mathrm{O} 1^{\mathrm{PA}}$ & $4.05(0.48)$ \\
\hline PW5 & $\mathrm{OH} 1^{\mathrm{w}} \cdots \mathrm{O} 2^{\mathrm{PA}}$ & $1.39(1.93)$ \\
\hline \multirow[t]{2}{*}{ PW6 } & $\mathrm{OH} 1^{\mathrm{w}} \cdots \mathrm{O} 2^{\mathrm{PA}}$ & $2.58(7.59)$ \\
\hline & $\mathrm{C} 1 \mathrm{H} 1^{\mathrm{PA} \cdots} \mathrm{O}^{\mathrm{W}}$ & 0.25 \\
\hline
\end{tabular}

a The values not in parentheses refer to $\mathrm{H}$-bond formation via the $\mathrm{O} \mathrm{sp}$ hybrid; those in parentheses refer to $\mathrm{H}-$ bond formation via the $\mathrm{O}$ p hybrid. See discussion in the text

The result of NBO analysis is listed in Table 4. The $\mathrm{O}$ atom involved as $\mathrm{H}-$ acceptor in PW2 $\left(\mathrm{C} 8 \mathrm{H} 8^{\mathrm{PA}} \cdots \mathrm{O} 2^{\mathrm{PA}}\right)$ and $\mathrm{PW} 6\left(\mathrm{C} 1 \mathrm{H} 1^{\mathrm{PA}} \cdots \mathrm{O}^{\mathrm{W}}\right)$ has one sp branch, respectively, while the $\mathrm{O}$ atom in other $\mathrm{H}$-bonds has two branches: one has sp hybrid characteristics, and the other one has p hybrid characteristics; they corresponds to two $E(2)$ values, respectively. Due to the largest $E(2)$ value of $11.37 \mathrm{kcal} \cdot \mathrm{mol}^{-1}$, the strongest CT effect happened in the $\mathrm{O} 1 \mathrm{H} 6^{\mathrm{PA}} \cdots \mathrm{O}^{\mathrm{W}} \mathrm{H}-$ bond of PW1 and made contribution to the hydrogen bonding interaction to a great extent. Moreover, the intermolecular $\mathrm{OH} 1^{\mathrm{w}} \cdots \mathrm{O} 2^{\mathrm{PA}}(\mathrm{PW} 6)$ have larger $E(2)$ values $\left(10.17 \mathrm{kcal} \cdot \mathrm{mol}^{-1}\right)$, so CT effect plays an important role in it. The $E(2)$ values of $\mathrm{H}$-bonds involving the methylene as $\mathrm{H}$-donor are less than $1.0 \mathrm{kcal} \cdot \mathrm{mol}^{-1}$ and are much smaller than those of the other $\mathrm{H}-$ bonds, which indicates that these $\mathrm{H}-$ bonds are very weak and is consistent with discussion above. It is pity that no direct $\mathrm{NBO}$ evidence for the $\mathrm{C} 8 \mathrm{H} 8^{\mathrm{PA}} \cdots \mathrm{O} 2^{\mathrm{PA}} \mathrm{H}-$ bond in some PA- $\mathrm{H}_{2} \mathrm{O}$ complexes (PW1, PW4 and PW6) was found, one reasonable explanation is that it is too weak in these complexes, and another possible reason is that the natural bond orbital is basically localization so that NBO cannot treat with such delocalization $\mathrm{H}-$ bond, which have been discussed in our previous works ${ }^{47}$.

The results of LMO-EDA are listed in Table 5. As shown in Table 5, the total interaction energy $(\Delta E)$ between $\mathrm{PA}$ and $\mathrm{H}_{2} \mathrm{O}$ moieties is whithin the range of about $-3.8 \sim-6.3 \mathrm{kcal} \times \mathrm{mol}^{-1}$, and the strongest $\Delta \mathrm{E}_{\mathrm{MP} 2}$ of -6.29 $\mathrm{kcal} \cdot \mathrm{mol}^{-1}$ indicates that PW6 is the most stable PA- $\mathrm{H}_{2} \mathrm{O}$ complex. In PW6, the largest stabilizing force is the exchange energy $\left(\Delta E_{\mathrm{e}}\right)$ of $-13.44 \mathrm{kcal} \cdot \mathrm{mol}^{-1}$, which origins from the overlap between the spin orbital of each monomer and the like-spin orbitals of the other monomer, but coming with a strong repulsion energy $\left(\Delta E_{\text {rep }}\right)$ of $24.05 \mathrm{kcal} \times \mathrm{mol}^{-1}$ simultaneously. The second largest stabilizing force is the electrostatic interaction $\left(\Delta E_{\text {ele }}\right)$ of $-12.77 \mathrm{kcal} \cdot \mathrm{mol}^{-1}$. Moreover, the formation of the $\mathrm{H}$-bond changes their orbital shapes of fragments and results in a polarization energy $\left(\Delta E_{\mathrm{pol}}\right)$ of $-3.74 \mathrm{kcal} \cdot \mathrm{mol}^{-1}$, which makes important contribution to the total interaction energy in PW6. In addition, the minor contribution to $\Delta E_{\mathrm{MP} 2}$ is the dispersion energy $\left(\Delta E_{\mathrm{disp}}\right)$ of $-0.39 \mathrm{kcal} \cdot \mathrm{mol}^{-1}$. In PW1, the second stable complex, 
Table 5. The LMO-EDA results of $\mathrm{PA}-\mathrm{H}_{2} \mathrm{O}$ complexes obtained at the MP2 level. Energy values are given in $\mathrm{kcal} \cdot \mathrm{mol}^{-1}$.

\begin{tabular}{|c|c|c|c|c|c|c|}
\hline complex & PW1 & PW2 & PW3 & PW4 & PW5 & PW6 \\
\hline$\Delta E_{\text {ele }}$ & -11.35 & -9.03 & -7.93 & -9.64 & -10.78 & -12.77 \\
\hline$\Delta E_{\text {ex }}$ & -11.75 & -9.22 & -9.49 & -11.06 & -11.51 & -13.44 \\
\hline$\Delta E_{\text {rep }}$ & 21.21 & 16.04 & 16.83 & 19.13 & 20.23 & -3.09 \\
\hline$\Delta E_{\mathrm{pol}}$ & -3.36 & -2.20 & -2.17 & -2.52 & -0.88 & -0.39 \\
\hline$\Delta E_{\text {disp }}$ & -0.90 & -0.95 & -1.00 & -1.57 & -6.02 & -6.29 \\
\hline$\Delta E_{\mathrm{MP} 2}$ & -6.16 & -5.35 & -3.76 & -5.66 & 0.45 & 0.22 \\
\hline$\Delta E_{\mathrm{prep}}$ & 0.11 & 0.17 & 0.51 & 0.15 & 24 \\
\hline
\end{tabular}

the main contributions to the second largest $\Delta E_{\mathrm{MP} 2}\left(-6.16 \mathrm{kcal} \cdot \mathrm{mol}^{-1}\right)$ mainly come from the larger $\Delta E_{\text {ele }}\left(-11.35 \mathrm{kcal} \cdot \mathrm{mol}^{-1}\right)$ and $\Delta E_{\text {ex }}(-11.75$ $\left.\mathrm{kcal} \cdot \mathrm{mol}^{-1}\right)$, while $\Delta E_{\mathrm{pol}}\left(-3.36 \mathrm{kcal} \cdot \mathrm{mol}^{-1}\right)$ and $\Delta E_{\text {disp }}\left(-0.90 \mathrm{kcal} \cdot \mathrm{mol}^{-1}\right)$ make less contribution to the $\Delta \mathrm{E}_{\mathrm{MP} 2}$ of PW1. Similar things also happened in PW2, PW4 and PW5 since they have almost same stabilities with each other. PW3 is the complex with less stabilities due to the smaller $\Delta E_{\mathrm{MP} 2}\left(-3.76 \mathrm{kcal} \cdot \mathrm{mol}^{-1}\right)$, which is attributed to the weaker hydrogen bonding interactions in it.

Our previous studies showed that hydrogen bonding interaction is not the unique factor for the stability of complexes involving hydrogen bonding interactions ${ }^{51-55}$. Therefore, the influence of the deformation of the monomers on the stability of PW complex were taken into account. On the basis of NBO theory, the preparation energy $\left(\Delta E_{\text {prep }}\right)$ is the amount of energy required to deform the separate bases from their free monomer structure to the geometry that they acquire in the pair complex,

$$
\Delta E_{\mathrm{prep}}=E_{\mathrm{PW}}-E_{\mathrm{PA}(\mathrm{W})}-E_{\mathrm{W}(\mathrm{PA})}
$$

here $E_{\mathrm{PA}(\mathrm{W})}$ (or $E_{\mathrm{W}(\mathrm{PA})}$ ) is the energy of the PA (or water) monomer when all the nucleus structure units of water (or PA) are considered as puppet atoms of carrying empty orbital. $\Delta \mathrm{E}_{\text {prep }}$ is positive because the structural deformation causes the molecular energy to jump to a higher energy level, while $\Delta E_{\mathrm{MP} 2}$ is negative unless the complex is less stable than the monomers. The preparation energies of all $\mathrm{PA}-\mathrm{H}_{2} \mathrm{O}$ complexes are also listed in Table 5 . All complexes have small $\Delta E$ values of less than about $0.7 \mathrm{kcal} \cdot \mathrm{mol}^{-1}$. The two largest $\Delta E$ values are 0.51 (PW3) and 0.45 (PW5) $\mathrm{kcal} \times \mathrm{mol}^{-1}$, which indicates that the cleavages of the intramolecular $\mathrm{C} 8 \mathrm{H} 8^{\mathrm{PA}} \cdots \mathrm{O} 2^{\mathrm{PA}} \mathrm{H}-$ bond in PW3 and PW5 result in the serious structural deformation and counteracts such strong hydrogen bonding interactions to a great extent. On the contrary, the intramolecular $\mathrm{C} 8 \mathrm{H} 8^{\mathrm{PA}} \cdots \mathrm{O} 2^{\mathrm{PA}} \mathrm{H}-$ bond was retained in other $\mathrm{PA}-\mathrm{H}_{2} \mathrm{O}$ complexes (PW1, PW2, PW4 and PW6), and the structural deformation of them are slight, which can be learned from their smaller $\Delta E_{\text {prep }}$ values in Table 5 . In one word, both hydrogen bonding interaction and structural deformation are the two important aspects of the stability of $\mathrm{PA}-\mathrm{H}_{2} \mathrm{O}$ complexes, which is consistent with our previous works ${ }^{51-55}$.

\section{CONCLUSIONS}

The geometries, energies and IR characteristics of the $\mathrm{H}-$ bonds of $\mathrm{PA}-\mathrm{H}_{2} \mathrm{O}$ complexes were studied at the MP2/6-311++G(d,p) level. The intramolecular $\mathrm{C} 8 \mathrm{H} 8^{\mathrm{PA}} \cdots \mathrm{O} 2^{\mathrm{PA}} \mathrm{H}-$ bond is retained in all complexes except $\mathrm{PW} 3$ and $\mathrm{PW} 5$. The intermolecular $\mathrm{O} 1 \mathrm{H}^{\mathrm{PA}} \cdots \mathrm{O}^{\mathrm{W}}(\mathrm{PW} 1)$ and $\mathrm{OH} 1^{\mathrm{W}} \cdots \mathrm{O} 2^{\mathrm{PA}}(\mathrm{PW} 6) \mathrm{H}-$ bonds are the two strongest ones. The $\mathrm{H}$-bonds involving the methylene of PA as $\mathrm{H}$-donors are very weak. Both hydrogen bonding interaction and structural deformation play important roles in the relative stabilities of the complexes. Except PW3, all $\mathrm{PA}-\mathrm{H}_{2} \mathrm{O}$ complexes have similar stabilities, which indicates that PA inclines to form various complexes when it meets with water solvent. These results further reinforce the concept that PA is considered as a good electron acceptor (or donor) in forming complexes with various small organic molecules. Therefore, we think that the studies on PA- $\mathrm{H}_{2} \mathrm{O}$ complexes maybe bear significance to the understanding the hydrogen bonding interactions between PA and other small organic molecules.

\section{ACKNOWLEDGEMENT}

This work is supported by the Natural Science Foundation of Tianjin (No. 12JCYBJC13400) and the Program for Innovative Research Team in University of Tianjin (TD13-5074).

\section{REFERENCES}

1. M. Sciskalska, M. Sliwinska-Mosson, M. Podawacz, W. Sajewicz and H. Milnerowicz, Drug. Chem. Toxicol. 38, 121 (2015).

2. W.S. Waring, H. Jamie and G.E. Leggett, Hum. Exp. Toxicol. 29, 63 (2010).

3. M. Naggayi, N. Mukiibi and E. Iliya, Afr. Health. Sci. 15, 598 (2015).

4. S.B.K. Mahadevan, P.J. McKiernan, P. Davies and D.A. Kelly, Arch. Dis. Child. 91, 598 (2006).

5. M. Cekmen, Y.O. Ilbey, E. Ozbek, A. Simsek, A. Somay and C. Ersoz, Food Chem. Toxicol. 47, 1480 (2009).

6. P. Abraham, Nephrology. 10, 623 (2005).

7. N.V. Nayyer, J. Byers and C. Marney, Brit. Dent. J. 216, 229 (2014).

8. P. Marzuillo, S. Guarino and E. Barbi, Eur. J. Pediatr. 173, 415 (2014)

9. A.-R. Marzilawati, Y.-Y. Ngau and S. Mahadeva, BMC Pharmacol. Toxico. 13, 8 (2012).

10. H. Jaeschke, Digest. Dis. 33, 464 (2015).

11. E.W. Holt, S. DeMartini and T.J. Davern, J. Clin. Gastroenterol. 49, 790 (2015).

12. G.G. Graham, M.J. Davies, R.O. Day, A. Mohamudally and K.F. Scott, Inflammopharmacology. 21, 201 (2013).

13. M.L. Ramos, J.F. Tyson and D.J. Curran, Anal. Proc. incl. Anal. Comm 32, 175 (1995)

14. P.A. Mosier-Boss, S.H. Lieberman and R. Newbery, Appl. Spectrosc. 49, 630 (1995).

15. B.B. Ivanova, J. Mol. Struct. 738, 233 (2005).

16. I.G. Binev, P. Vassileva-Boyadjieva and Y.I. Binev, J. Mol. Struct. 447, 235 (1998)

17. E. Dreassi, G. Ceramelli, P. Corti, M. Massacesi and P.L. Perruccio, Analyst. 120, 2361 (1995).

18. J.M. Beames and A.J. Hudson, Phys. Chem. Chem. Phys. 12, 4157 (2010)

19. Y. Danten, T. Tassaing and M. Besnard, J. Phys. Chem. A. 110, 8986 (2006)

20. S.J. Lee, A. Min, Y. Kim, A. Ahn, J. Chang, S.H. Lee, M.Y. Choi and S.K. Kim, Phys. Chem. Chem. Phys. 13, 16537 (2011).

21. M. Yoosefian and N. Etminan, RSC Adv. 5, 31172 (2015).

22. S. Rai, H. Singh and U.D. Priyakumar, RSC Adv. 5, 49408 (2015).

23. K.H. Moller, A.S. Hansen and H.G. Kjaergaard, J. Phys. Chem. A. 119, 10988 (2015).

24. M. Izadyar, M. Khavani and M.R. Housaindokht, Phys. Chem. Chem. Phys. 17, 11382 (2015)

25. Z.G. Huang, Y.M. Dai and L. Yu, Struct. Chem. 21, 863 (2010).

26. L.F. Guo, Z.G. Huang, T.T. Shen, L.L. Ma and X.Q. Niu, Chin. J. Chem 31, 1079 (2013).

27. P.L.A. Popelier: Atoms in Molecules: An Introduction (Prentice Hall, City, 2000).

28. C.F. Matta and R.J. Boyd: The Quantum Theory of Atoms in Molecules: From Solid State to DNA and Drug Design (WILEY-VCH Verlag GmbH \& Co. KGaA, City, 2007).

29. A.E. Reed, L.A. Curtiss and F. Weinhold, Chem. Rev. 88, 899 (1988).

30. P.F. Su and H. Li, J. Chem. Phys. 131, 014102 (2009).

31. J. Xi and X. Xu, Phys. Chem. Chem. Phys. 18, 6913 (2016).

32. S.K. Singh, S. Kumar and A. Das, Phys. Chem. Chem. Phys. 16, 8819 (2014).

33. J.J. Panek, A. Filarowski and A. Jezierska-Mazzarello, J. Chem. Phys. 139, 154312 (10 pp.) (2013).

34. A. Lakshmipriya, S.R. Chaudhari, A. Shahi, E. Arunan and N Suryaprakash, Phys. Chem. Chem. Phys. 17, 7528 (2015). 
35. M. Jablonski and M. Palusiak, J. Phys. Chem. A. 116, 2322 (2012).

36. L.L. Ma, Z.G. Huang, X.Q. Niu, T.T. Shen and L.F. Guo, Comput. \& Theor. Chem. 1017, 14 (2013).

37. E. Espinosa, I. Alkorta, J. Elguero and E. Molins, J. Chem. Phys. 117, 5529 (2002).

38. U. Koch and P.L.A. Popelier, J. Phys. Chem. 99, 9747 (1995).

39. W.D. Arnold and E. Oldfield, J. Am. Chem. Soc. 122, 12835 (2000).

40. S. Jenkins and I. Morrison, Chem. Phys. Lett. 317, 97 (2000).

41. S.J. Grabowski, W.A. Sokalski and J. Leszczynski, J. Phys. Chem. A. 110, 4772 (2006).

42. L.F. Pacios, J. Phys. Chem. A. 108, 1177 (2004).

43. A.E. Reed, F. Weinhold, L.A. Curtiss and D.J. Pochatko, J. Chem. Phys. 84, 5687 (1986).

44. M.J. Frisch, G.W. Trucks, H.B. Schlegel, G.E. Scuseria, M.A. Robb, J.R. Cheeseman, G. Scalmani, V. Barone, B. Mennucci, G.A. Petersson, H. Nakatsuji, M. Caricato, X. Li, H.P. Hratchian, A.F. Izmaylov, J. Bloino, G. Zheng, J.L. Sonnenberg, M. Hada, M. Ehara, K. Toyota, R. Fukuda, J. Hasegawa, M. Ishida, T. Nakajima, Y. Honda, O. Kitao, H. Nakai, T. Vreven, J.A. Montgomery Jr., J.E. Peralta, F. Ogliaro, M. Bearpark, J.J. Heyd, E. Brothers, K.N. Kudin, V.N. Staroverov, R. Kobayashi, J. Normand, K. Raghavachari, A. Rendell, J.C. Burant, S.S. Iyengar, J. Tomasi, M. Cossi, N. Rega, J.M. Millam, M. Klene, J.E. Knox, J.B. Cross, V. Bakken, C. Adamo, J. Jaramillo, R. Gomperts, R.E. Stratmann, O. Yazyev, A.J. Austin, R. Cammi, C. Pomelli, J.W. Ochterski, R.L. Martin,
K. Morokuma, V.G. Zakrzewski, G.A. Voth, P. Salvador, J.J. Dannenberg, S. Dapprich, A.D. Daniels, Ö. Farkas, J.B. Foresman, J.V. Ortiz, J. Cioslowski and D.J. Fox: Gaussian09, (Gaussian, Inc., City, 2009).

45. F. Biegler-König and J. Schönbohm: AIM2000, (University of Applied Sciences, City, 2000)

46. M.W. Schmidt, K.K. Baldridge, J.A. Boatz, S.T. Elbert, M.S. Gordon, J.H. Jensen, S. Koseki, N. Matsunaga, K.A. Nguyen, S. Su, T.L. Windus, M. Dupuis and J.A. Montgomery, J. Comput. Chem. 14, 1347 (1993).

47. H.K. Wang, Z.G. Huang, T.T. Shen and L.F. Guo, Struct. Chem. 23, 1163 (2012).

48. H.K. Wang, Z.G. Huang, T.T. Shen and L.F. Guo, J. Mol. Model. 18, 3113 (2012).

49. L. Yu, Y.H. Wang, Z.G. Huang, H.K. Wang and Y.M. Dai, Int. J. Quantum Chem. 112, 1514 (2012).

50. X.Q. Niu, Z.G. Huang, L.L. Ma, T.T. Shen and L.F. Guo, J. Chem. Sci. 125, 949 (2013).

51. Z.G. Huang, L. Yu, Y.M. Dai and H.K. Wang, Struct. Chem. 22, 57 (2011)

52. Z.G. Huang, L. Yu and Y.M. Dai, Int. J. Quantum Chem. 111, 3915 (2011).

53. Z.G. Huang, Y.M. Dai, L. Yu and H.K. Wang, J. Mol. Model. 17, 2609 (2011)

54. Z.G. Huang, L. Yu, Y.M. Dai and H.K. Wang, J. Mol. Struct. (Theochem). 960, 98 (2010).

55. Z.G. Huang, L. Yu and Y.M. Dai, Struct. Chem. 21, 855 (2010). 